Tomasz Siwiec

Gdańsk

ORCID: 0000-0003-3934-1788

e-mail: tomasz.siwiec8@wp.pl

Michał Rydlewski

Uniwersytet Wrocławski

ORCID: 0000-0001-7055-1252

e-mail: rydles@autograf.pl

Radosław Wiśniewski

Interaktywne Muzeum Państwa Krzyżackiego, Działdowo

ORCID: 0000-0002-0847-2606

e-mail: wisniewskiradek@interia.pl

\title{
Wspomnienie o doc. Stanisławie Soldenhoffie (1928-2019)
}

DOI: http://dx.doi.org/10.12775/RF.2019.011

W listopadzie 2009 roku trzech słuchaczy I roku studiów doktoranckich w Instytucie Filozofii Uniwersytetu Mikołaja Kopernika w Toruniu przeprowadziło z Docentem Doktorem Stanisławem Soldenhoffem obszerną rozmowę, która ukazała się na łamach „Ruchu Filozoficznego"1. Jak się miało okazać, byli oni przedstawicielami ostatniego rocznika studentów, którzy z Docentem Soldenhoffem mieli styczność na zajęciach akademickich. Kiedy informacja o śmierci Doktora Soldenhoffa została podana do publicznej wiadomości, wspomniana trójka zwróciła się do

1 "Ze Stanisławem Soldenhoffem rozmawiają Michał Rydlewski, Tomasz Siwiec i Radosław Wiśniewski", Ruch Filozoficzny 4 (70) (2013): 778-809. 
naszej redakcji z prośbą o możliwość opublikowania krótkiego wspomnienia, co postanowiliśmy im umożliwić. Ostatecznie ułożyło się ono w formę trójgłosu, który ma wspólny mianownik: opowiada o lekcji życia, jakiej Stanisław Soldenhoff - być może nawet nieświadomie - udzielił młodym ludziom.

\section{Tomasz Siwiec}

Nie pamiętam tytułu seminarium, które w roku akademickim 2008/2009 prowadził w Instytucie Filozofii Uniwersytetu Mikołaja Kopernika Profesor Stanisław Soldenhoff. Pamiętam jedynie pełne napięcia oczekiwanie na pierwsze zajęcia. W 2008 roku, kiedy rozpoczynaliśmy studia doktoranckie, Profesor Soldenhoff był już od wielu lat na emeryturze. Nie widywało się Go na korytarzach Instytutu ani nie można było Go spotkać $\mathrm{w}$ akademickiej stołówce. $\mathrm{Z}$ drugiej strony nasi wykładowcy niejednokrotnie wspominali Profesora jako człowieka, który w trudnych latach realnego socjalizmu kierował Instytutem Nauk Społecznych UMK i w dużej mierze był odpowiedzialny za obecny kształt Instytutu Filozofii. Wspominano Go jako współpracownika Tadeusza Czeżowskiego i Henryka Elzenberga, którzy dla nas byli ojcami-założycielami toruńskiego Instytutu Filozofii. Krótko mówiąc, Profesora Soldenhoffa spowijała aura tajemniczości i legendy. Być może dlatego równe naszemu oczekiwaniu było rozczarowanie, jakie pojawiło się po pierwszych zajęciach, które nie były ani popisem filozoficznej erudycji prowadzącego, ani przykładem intelektualnej ekwilibrystyki, jaką częstokroć jest analiza tekstów filozoficznych. Na zajęciach prowadzonych przez Profesora Soldenhoffa filozofii było niewiele, a przynajmniej tak nam się wówczas wydawało. Nasze przekonanie niewątpliwie było syndromem intelektualnego ograniczenia, które znakomity niemiecki filozof Herbert Schnädelbach określił mianem morbus hermeneuticus. Choroba ta polega na przeświadczeniu, że jeśli ktoś pragnie mieć udział w filozofii, musi interpretować teksty wielkich myślicieli, ponieważ historia filozofii rozwija się przez wykładnię i aplikację ich tekstów ${ }^{2}$. Nic dziwnego, że zainfekowani tą chorobą byliśmy zdania, że seminarium Profesora Soldenhoffa - pełne anegdot, wspomnień i swobodnych przemyśleń o życiu codziennym - nie ma nic wspólnego z filozoficznym myśleniem i tym samym dla młodych adeptów filozofii, za jakich wówczas zarozumiale się uważaliśmy, jest zwyczajną stratą czasu.

2 Herbert Schnädelbach, "Morbus hermeneuticus - tezy na temat pewnej choroby filozoficznej", w: Herbert Schnädelbach, Rozum i historia. Odczyty i rozprawy 1, przeł. K. Krzemieniowa (Warszawa: Oficyna Naukowa, 2001), 221-227. 
Cóż zatem takiego się wydarzyło, że na początku listopada 2009 roku wraz z dwoma kolegami - Michałem Rydlewskim i Radkiem Wiśniewskim - pojawiliśmy się w toruńskim mieszkaniu Stanisława Soldenhoffa celem przeprowadzenia obszernej rozmowy o jego życiu, doświadczeniach, drodze zawodowej i ludziach, którzy Mu na niej towarzyszyli? Dlaczego nagle zapragnęliśmy rozmawiać z Człowiekiem, którego zajęcia uważaliśmy jeszcze do niedawna za stratę czasu i nudne pamiętnikarstwo? Myślę, że kiedy skończył się semestr i tym samym zakończyło się wspomniane seminarium, zrozumieliśmy wartość i wyjątkowość tych wspomnień. Przestaliśmy na Profesora Soldenhoffa projektować nasze oczekiwania i wyobrażenia, a pozwoliliśmy dojść do głosu temu, co tak skutecznie przesłaniała nasza "hermeneutyczna choroba” - doświadczeniu życia i wiekowej mądrości Prowadzącego. Kiedy najgroźniejsze symptomy choroby minęły, a my obudziliśmy się z „dogmatycznej drzemki" (bo czymże innym było nasze przekonanie, że filozofia wyczerpuje się w filozoficznym literaturoznawstwie), wówczas zobaczyliśmy nietuzinkową osobowość, łagodność charakteru, życzliwość, wyjątkowe poczucie humoru i bezpośredniość, która tak bardzo nas ujęła. I zapragnęliśmy więcej. Taka jest genealogia przeprowadzonej dziesięć lat temu rozmowy, ale taka jest również etiologia naszej „hermeneutycznej choroby" oraz ozdrowienia, w którym pomogła nam pierwsza lekcja, jakiej udzielił nam Profesor Stanisław Soldenhoff.

Pamiętam moje ostatnie spotkanie z Profesorem Soldenhoffem w 2015 roku. Po zakończeniu uroczystości jubileuszowych Profesora Ryszarda Wiśniewskiego z okazji jego sześćdziesiątych piątych urodzin odwoziłem Profesora Soldenhoffa do jego domu na toruńskim Rubinkowie. Pomogłem mu wysiąść z samochodu. Profesor silnie uścisnął mi dłoń i powiedział: „Niech pan do mnie zadzwoni, bardzo proszę. Serdecznie pana zapraszam na herbatę. Proszę do mnie przyjechać, chętnie z panem porozmawiam". Bardzo ucieszyło mnie to zaproszenie i odpowiedziałem, że z pewnością zadzwonię, czego jednak nie uczyniłem. Problemy osobiste, zmiana planów zawodowych i niespodziewana przeprowadzka z Torunia do Gdańska udaremniły moje dobre chęci. Będąc w Gdańsku, wielokrotnie wracałem w myślach do wystosowanego zaproszenia i powtarzałem sobie, że muszę zadzwonić do Profesora Soldenhoffa, jak tylko będę w Toruniu. W piątek 25 stycznia 2019 roku wyjeżdżałem do Warszawy i - przygotowując się do podróży - pomyślałem, że w kolejnym tygodniu, w czasie mojej wizyty w Toruniu, zadzwonię do Profesora. Dwa dni później otrzymałem od Michała Rydlewskiego wiadomość, że Profesor Stanisław Soldenhoff nie żyje. Zmarł w dniu mojego wyjazdu do Warszawy, kiedy po raz „enty” obiecałem sobie, że do Niego zadzwonię. To była druga, tym razem bardzo gorzka lekcja, jakiej na pożegnanie Profesor mi udzielił. Dlaczego akurat tego piątkowego przedpołudnia, pakując walizkę, pomyślałem o Profe- 
sorze? Nie mam pojęcia i jestem jak najdalszy od poszukiwania jakiejkolwiek „metafizycznej koincydencji”. Przypominają mi się jedynie słowa Profesora, które wypowiedział na zakończenie przeprowadzanej z nami rozmowy: „Mówię wam, najwięcej tajemnic jest pod ręka, niech się wypchają z astrologią i horoskopami".

Niewątpliwie wśród naszych wykładowców są osoby, które Profesora Stanisława Soldenhoffa znały znacznie dłużej i znacznie lepiej niż my. Był ich przełożonym, promotorem, kolegą. Niewątpliwie istnieją osoby, dla których był znacznie bliższy i z którymi miał kontakt znacznie mniej akcydentalny niż z nami. Ale to, że po dziesięciu latach od przeprowadzenia tej pamiętnej dla nas rozmowy mamy potrzebę napisania o Nim chociażby krótkiego wspomnienia, jest niewątpliwie świadectwem siły Jego osobowości. Wasilij Rozanow pisał, że „wspomnienie o dobrym uczynku, o łagodnych i delikatnych stosunkach, to jedyny jasny gość w izbie duszy"3. Profesor Stanisław Soldenhoff był takim ",jasnym gościem" i takim też pozostanie w mojej pamięci.

\section{Michał Rydlewski}

O śmierci Profesora Stanisława Soldenhoffa ${ }^{4}$ dowiedziałem się przypadkowo. Na profilu facebookowym Profesora Lecha Witkowskiego ukazała się informacja Uniwersytetu Mikołaja Kopernika w Toruniu o dacie i godzinie pogrzebu toruńskiego filozofa i etyka. Było tam zawartych kilka informacji biograficznych oraz zdjęcie. Zdjęcie z czasów, kiedy Profesor był młodym człowiekiem. To zdjęcie przywołało fragment naszej rozmowy, w której Profesor mówił o obozie naukowo-dydaktycznym w Tleniu:

[...] wymyśliłem taki obóz w Tleniu, naukowo-wypoczynkowy, udało się załatwić na to pieniądze. Mieszkałem wtedy w Grzybku, sześć kilometrów od Tlenia i dopływałem tam łódką. Pamiętam, że dziewczyny na mnie zawsze czekały z poziomkami, malinami, z koglem moglem, strasznie mnie hołubiły, nigdy tego nie zapomnę (śmiech).

Chociaż poznałem Profesora, kiedy był już na emeryturze ${ }^{5}$, to gdy Go wspominam, widzę zawsze obecną w Nim młodzieńczość przejawiającą się $\mathrm{w}$ kapitalnym poczuciu humoru, umiejętności obserwacji

3 Wasilij Rozanow, Odosobnione (niemal na prawach rękopisu), przeł. Ireneusz Kania, Piotr Nowak (Warszawa: Fundacja Augusta hr. Cieszkowskiego, 2014), 118-119.

4 Stanisław Soldenhoff nie miał tytułu profesorskiego, co sam zresztą podkreślał. Był doktorem i zajmował stanowisko docenta, ale w tekście będę używał określenia „Profesor".

5 Profesor Soldenhoff prowadził zajęcia dla doktorantów. 
rzeczywistości z dystansem i ironią, radości życia i jednoczesnym jej kontemplowaniu, docenieniu piękna przyrody i piękna ludzi. Wszystko to jest widoczne w przeprowadzonej przez naszą trójkę rozmowie, która była i jest dla mnie ważną lekcją.

Lekcją o czym? Lekcją czego?

$\mathrm{W}$ swoim pokoju w instytucie, gdzie obecnie pracuję, zostawiłem kiedyś kilka książek, egzemplarze, które miałem podwójne. Zaniosłem między innymi numer „Ruchu Filozoficznego", w którym ukazała się nasza rozmowa. Leżał na dolnej półce. Tak, jak i leży do dzisiaj. Były takie momenty, że brałem ten numer do ręki, czytałem wyrywkowo kilka ulubionych fragmentów i zanosiłem się śmiechem. I wracał wtedy do mnie Toruń, wracała ta rozmowa, wracali moi Koledzy, nasze rozmowy, nasze spory, to wszystko, co było, a czego już nie ma i co nie wróci. Zawsze po tym czułem się obcy. Wiedziałem, że jestem nie na miejscu, chociaż nie jest mi tutaj źle. Ważność tej rozmowy docierała do mnie partiami. W chwili gdy rozmawialiśmy z Profesorem, nie miałem poczucia, że robimy coś wyjątkowego. Potem przyszło przepisywanie rozmowy. Zrobiliśmy to wespół z Radkiem. Tomek dokonał redakcji i uzupełnił rozmowę o bardzo ważne przypisy rzucające światło na filozoficzny świat Profesora. Wymyślił też znakomity tytuł (z Goethego: „Mów mi Baronie, bo to pięknie brzmi..."), który jednak, z nieznanych mi względów, nie pojawił się w wersji opublikowanej. Może to zwykłe przeoczenie, a może komuś nie podobało się zbyt daleko idące nadszarpnięcie powagi Profesora? Nie wiem też, czy mamy jeszcze nagranie. Chciałbym ponownie usłyszeć Jego głos. Ta rozmowa stała się ważna jakiś czas później. Kiedy już nie było Torunia („Toruń” to taka moja metafora tamtych czasów). I kiedy byłem sam. Zrozumiałem wówczas wiele rzeczy i poczułem się jeszcze bardziej samotny. Myślałem, co robią moi Koledzy, gdzie sa, czym się zajmuja, co każdy z nas będzie robił w życiu. Słowem: co się z nami stało. Choć dzwonimy do siebie czasami, to nie to samo, co wtedy. Brakuje mi tego, bo choć lubię być sam, to nie umiem żyć poza wspólnotą. Kiedy biorę wspomniany tom „Ruchu Filozoficznego” do ręki, na chwilę wraca „Torun". Znam na pamięć tę rozmowę, mogę cytować długie jej fragmenty. Lubię jej zakończenie; o tym, że najwięcej tajemnic jest pod ręką.

Ta rozmowa wraca do mnie w nieoczekiwanych momentach - wtedy, kiedy dzieją się takie małe, niezauważalne w życiu codziennym epifanie, kiedy udaje mi się w jednym momencie rozszyfrować kod przemawiającego do mnie świata.

Jakiś czas temu w moim ogródku zmarł wróbelek. Obserwowałem go przez chwilę. Położył się spokojnie i widać było, że jeszcze żyje, ale nigdy już nie poleci. I wtedy przypomniały mi się słowa Profesora o tych umierających ptakach $\mathrm{u}$ niego na balkonie. Dałem umrzeć spokojnie temu wróbelkowi, a potem go pochowałem w ogródku. Pogłaskałem 
swojego psa i patrzyłem na półkę z tomem „Ruchu Filozoficznego”. Wiedziałem, że muszę wrócić do pisania sylabusów i zająć się inną pracą odciągającą od nauki. Myślałem wtedy o tej jawnie wypowiadanej przez Profesora niechęci do biurokracji. I przypomniałem sobie też, że Profesor nazywał zajęcia, jakie mu przydzielono, „klatkami”. Kiedyś nawet tak zażartowałem w sekretariacie instytutu: jakie i kiedy mam klatki? Nikt nie zrozumiał.

Kiedyś na jednym z moich wykładów zasnęła studentka. Obudzona przez koleżankę, przeprosiła z zażenowaniem. Powiedziałem, że to nie problem, gorzej by było, gdybym to ja zasnął, co było oczywiście niezrozumiałym dla nikogo nawiązaniem do Profesora, któremu to się zdarzyło. Wszyscy studenci wybuchnęli śmiechem, bo trudno im było uwierzyć, że taka sytuacja może mieć miejsce. Otóż może.

Wiem jedno: spotkanie z Panem Profesorem było dla mnie ważne, chociaż nie zajmowałem się Jego "terenem” filozofii, a nawet nie znam Jego książek. To było spotkanie, przynajmniej dla mnie, z Człowiekiem. Teraz patrzę, jakie drzewa wycinają i myślę, że ptaki nie będą miały gdzie siadać. Czegoś się nauczyłem. I nie chodzi tylko o drzewa i ptaki. Kiedyś, gdy studiowałem etnologię na Uniwersytecie Warszawskim, moja nieżyjąca już promotor pracy magisterskiej, profesor Anna Zadrożyńska, powiedziała mi, że życia trzeba się nażąć i wykonała gest koszenia. To jest ta lekcja.

Na koniec powiem, że przeczytałem wspomnienia Kolegów. Radek uświadomił mi, jak wiele z Człowieka i jego idiolektu wchodzi do naszego słownika i poprzez to kształtuje nasze postrzeganie świata. Tomek z kolei zwrócił moją uwagę, że niczego w życiu nie należy odkładać na później. To lekcja, którą Profesor dał nam wszystkim: trzeba żyć, bo nie wiadomo, ile jeszcze tego życia nam zostało. Dzisiaj do Ciebie, Tomku, zadzwonię.

\section{Radosław Wiśniewski}

Nie ukrywam, że nazwisko Profesora Stanisława Soldenhoffa niewiele mi mówiło, kiedy dowiedziałem się, że będę miał z nim seminarium na studiach doktoranckich. Przejrzałem Internet, popytałem kolegów, którzy kończyli magisterium w Toruniu (ja byłem z zewnątrz) i dowiedziałem się, że Profesor Soldenhoff to ikona środowiska filozoficznego Uniwersytetu Mikołaja Kopernika w Toruniu. Człowiek, który swoje pierwsze szlify zdobywał u takich sław, jak: Tadeusz Czeżowski, Henryk Elzenberg, Adam Shaff, Marek Fritzhand czy Tadeusz Szczurkiewicz. Pisałem wówczas doktorat, zbierałem materiały, rozmyślałem nad metodologią rozprawy, a wieść, że będę mógł posłuchać wykładów tak wybitnej klasy fachowca, bardzo mnie ucieszyła. Pamiętam moment, 
kiedy profesor wszedł do sali, troszkę przygarbiony - bo był już wówczas starszym człowiekiem - $\mathrm{z}$ materiałową, wysłużoną torbą $\mathrm{w}$ ręce, bardzo podobną do tej, jaką miał mój dziadek. Nie zdążył jeszcze przedstawić się ani usiąść, ale powiedział do nas głośno: „Fajne tu macie dziewuchy w tym instytucie! Zapraszacie je do kawiarni?".

Pierwsze zajęcia mnie rozczarowały. Profesor Soldenhoff nie mówił za wiele o filozofii, nie zgłębiał, dajmy na to: monadologii Leibniza, fenomenologii Husserla czy dekonstrukcjonizmu Derridy. Pamiętam, że Michał Rydlewski też był zawiedziony, chyba o wiele bardziej niż ja. Utkwiło mi w pamięci, jak schodził po schodach i krzyknął do mnie na półpiętrze: „Piszę doktorat, nie mam czasu jeździć na zajęcia 40 minut autobusem i nic $\mathrm{z}$ nich nie wynosić, mógłbym przecież $\mathrm{w}$ tym czasie napisać kilka stron!". Ale Profesor Soldenhoff był skrupulatny, opowiadał nam o mądrości, o tym, co w życiu ważne, a co błahe, o tym, żeby nie przejmować się za bardzo pisaniem doktoratu, bo na świecie jest wiele innych, pożyteczniejszych czynności, np. pójście do kawiarni. Pamiętam, jak kiedyś na zajęciach nasz nauczyciel przeprowadził kapitalną analizę różnorodności charakterów i natur ludzkich, osadzając na dwóch biegunach Józefa Stalina i Jana Pawła II. Po jakimś miesiącu zajęcia z Profesorem stały się moimi ulubionymi, a Michał - i tu nie przesadzam - nie mógł bez nich żyć do tego stopnia, że zaproponował mi i Tomaszowi Siwcowi zrobienie wywiadu z naszym wykładowcą. Zgodziliśmy się z Tomkiem bez wahania.

Wchodząc do pokoju Profesora Soldenhoffa, jedno od razu dało się zauważyć: półmrok, a przy fotelu starą lampę, na której wisiał duży, pomarańczowy klosz. Lampa raczej zdobiła pokój Profesora, niż go oświetlała. Zapamiętałem ten szczegół, ponieważ moja babcia miała bardzo podobną lampę - będąc jeszcze w wieku szkolnym, przy jej świetle często odrabiałem pracę domową. Profesor ze swoim niezwykłym poczuciem humoru, którego nigdy mu nie brakowało, powiedział do nas: „Wchodźcie, panowie, rozgośćcie się, tam żona coś przygotowała, może napijecie się jakiegoś koniaku czy wina, jest troszkę ciemno, ale wiecie, ja nie lubię tych cholernych górnych świateł". Pomyślałem sobie wówczas, że mimo dużej różnicy wieku łączy mnie z Profesorem takie samo upodobanie: odkąd pamiętam, ja też nie lubiłem górnych świateł, zwłaszcza tych ledowych, białych, nieprzyjemnych dla oka.

Kilka lat później, gdy pracowałem z Tomkiem w jednej z firm na Pomorzu, często wspominaliśmy Profesora Soldenhoffa. Wchodziliśmy do biur bardzo wcześnie rano, kiedy nikogo jeszcze w nich nie było, i najpierw parzyliśmy: ja kawę, Tomek herbatę (najlepiej w litrowym kubku, bo na długo starcza i nie trzeba w kółko dolewać). Zaraz potem słyszałem: „Radku, nie włączaj tych cholernych górnych świateł”. Siedzieliśmy w ciemni i pracowaliśmy; szkoda, że nie mieliśmy tam takiej lampy, jaka była u Profesora. Tomek dodawał wtedy: ,Zobaczysz, zaraz zacznie 
się »wariactwo «". („Wariactwo" i "cholerstwo" to dwa często powtarzane przez Profesora podczas wywiadu słowa, które dobrze zapamiętaliśmy i których chętnie używamy). Tomek miał po prostu na myśli to, że niebawem wejdą nasze głośne koleżanki, zaczną nas rozpraszać, mówić o wczorajszych zakupach, o pogodzie, o tym, czy w końcu rozwiąże się kluczowy problem dla losów świata, mianowicie: czy serialowy Pedro zdradzi Lusesitę, a może odwrotnie. A co najgorsze, że zaraz rozświecą się ledowe, białe światła i skończy się nasza spokojna praca, a zacznie hałas, harmider, słowem: istne „wariactwo”. Niestety, Tomek w tym względzie zawsze miał rację.

Czytałem wspomnienia Michała, które przesłał mi kilka dni temu. Fragment o wróbelku troszkę mnie wzruszył. Profesor opowiadał, że w dojrzałym okresie swojego życia coraz mocniej zajmowała Go ornitologia, kosztem filozofii. Pamiętam, jak charakteryzował poszczególne gatunki ptaków: sikorki nie potrafią żyć bez ruchu, ciągle flirtują i kokietuja, jaskółki natomiast to typowe indywidualistki (swoją drogą, ciekawe co by na to powiedział Nietzsche czy Stirner). Może kiedyś ornitologia pochłonie Michała bardziej niż filozofia, a my z Tomkiem nie omieszkamy wówczas wykorzystać tego faktu. Kupimy atlas ornitologiczny. Już widzę tę skrywaną za okularami łzę Michasia, wycieraną po kryjomu chusteczką - bo to bardzo wrażliwy człowiek - a przy tym moją i Tomka wymianę spojrzeń i uśmiechów. Wspomnimy wówczas śp. Pana Profesora Stanisława Soldenhoffa, a historia zatoczy koło. 